University of Michigan Law School

University of Michigan Law School Scholarship Repository

\title{
The Liability of the Common Carrier as Determined by the Recent Decisions of the United States Supreme Court
}

\author{
Edwin C. Goddard \\ University of Michigan Law School
}

Available at: https://repository.law.umich.edu/articles/1288

Follow this and additional works at: https://repository.law.umich.edu/articles

Part of the Commercial Law Commons, Common Law Commons, Courts Commons, Supreme Court of the United States Commons, Torts Commons, and the Transportation Law Commons

\section{Recommended Citation}

Goddard, Edwin C. "The Liability of the Common Carrier as Determined by the Recent Decisions of the United States Supreme Court." Colum. L. Rev. 15 (1915): 399-416, 475-88.

This Article is brought to you for free and open access by the Faculty Scholarship at University of Michigan Law School Scholarship Repository. It has been accepted for inclusion in Articles by an authorized administrator of University of Michigan Law School Scholarship Repository. For more information, please contact mlaw.repository@umich.edu. 


\section{THE LIABILITY OF THE COMMON CARRIER AS DETERMINED BY RECENT DECI- SIONS OF THE UNITED STATES SUPREME COURT.}

I.

An understanding of the present day liability of the common carrier under conditions as they exist, especially in interstate shipments, is best reached by an historical journey from the early decisions of the Supreme Court of the United States to the end of the year just past.

It has usually been assumed that Lord Holt, in his famous opinion in Coggs v. Bernard, ${ }^{1}$ but announced common law, already well settled before his day, when he said that if a delivery of goods to carry or otherwise manage is made to one who exercises a public employment, "and he is to have a reward, he is bound to answer for the goods at all events. . . . The law charges this person thus entrusted to carry goods, against all events but acts of God, and of the enemies of the king." The reason, in the quaint language of the great chief justice, is that "this is a politic establishment, contrived by the policy of the law, for the safety of all persons, the necessity of whose affairs obliges them to trust these sort of persons, that they may be safe in their ways of dealing; for else these carriers might have an opportunity of undoing all persons that had any dealings with them, by combining with thieves, and so forth, and yet doing it in such clandestine manner, as would not be possible to be discovered."

Mr. Justice Holmes ${ }^{2}$ makes a strong case against the assumption that the law had thus been settled before Lord Holt announced it, or that it is a correct statement of the origin of the law as it existed down to Lord Holt's day. Justice Holmes denies that the strict rule of liability of the common carrier was on the one hand borrowed from the Romans, ${ }^{3}$ or that on the other hand it was engrafted on the English law in the reigus of Elizabeth and James I, as an exception to the general law of bailment. ${ }^{4}$ Rather, he urges, is it a fragmentary survival of the early general law of

${ }^{1}$ (1702) 2 Ld. Raym. 909, 918.

${ }^{2}$ The Common Law, p. I8o, et seq.

${ }^{3}$ Nugent v. Smith (1875) I C. P. D. 28, per Brett, J.

Nugent $v$. Smith (1876) I C. P. D. 428, per Cockburn, C. J. 
bailment which made a bailee liable to the bailor at all events, and with no exceptions, even for losses caused by the act of God or the King's enemies. The English rule was quite different from the rule of the Civil Law, which excused the carrier for losses due to inevitable accident, whether by the act of God, or the public enemy, or uncontrollable human causes, and also from Lord Holt's announcement of it, which excepted losses caused by the act of God or the public enemy.

Whatever the historical facts may be, certain it is that this absolute liability of the bailee long since ceased as to all others except those engaged in a public calling, and as to all of these last except as to the innkeeper and the common carrier. It has even been warmly disputed that it ever extended to the innkeeper for losses caused by inevitable accident. ${ }^{5}$ Certainly it does not extend to public callings in general, such for example as log booming companies, wharfingers, warehousemen and elevator owners, whose business may have become affected with a public interest, and therefore be subject to public regulation. Grant if you will that Lord Holt read into the old precedents his conception of public policy, and that later judges read into his reasonings their conceptions, the fact remains that in all the changes in the course of which the surgeon, the farrier, the baker, the miller, the tailor, and every other person taking upon himself a public employment, as it was regarded in Lord Holt's day, ceased to be subject to special rules because of the public nature of their business, the innkeeper and the common carrier have ever been held to be subject to exceptional duties and liabilities. Not even the laissez faire period of the late eighteenth and early nineteenth centuries, in its reaction from the highly organized regulated society of Lord Hale's day, ever relaxed in the least the strictness of the rule announced by Lord Holt and in I785 adopted by Lord Mansfield and by him firmly fastened upon our law in the case of Forward v. Pittard:" ". . . to prevent litigation, collusion, and the necessity of going into circumstances impossible to be unravelled, the law presumes against the carrier unless he shews it was done by the King's enemies, or by such act as could not happen by the intervention of man, as storms, lightning and tempests." This rule Lord Mansfield limits, however, to the common carrier, and later cases have extended the exceptions to cover losses due to the

${ }^{8} \mathrm{Cf}$. Sibley $v$. Aldrich (1856) 33 N. H. 553, and Cutler $v$. Bonney (I874) 30 Mich. 259.

${ }^{\circ}(1785)$ I T. R. $27,33$. 
exercise of public authority, to the fault of the shipper, and to the inherent vice of the thing shipped. The early years of the last century saw many occupations brought under special rules because of the public nature and importance of their business, and since the great case of Munn v. Illinois, ${ }^{7}$ there has been a considerable return in the direction of greater regulations of a large number of callings, akin to the conditions prevailing in Lord Hale's day, and which he described in his works De Portibus Maris and De Jure Maris, so much relied upon by the court in Munn v. Illinois. But we are here concerned only with the fact that amid all changes the carrier, from Lord Holt's day down, has been regarded as an insurer, with certain exceptions.

The strict rnle of liability of the common carrier was adopted at a time when the highways in England were bridle paths through the forests, when they were infested with robbers, and when means of communication were few and slow. All this has been changed, and yet the courts have ever resisted all effort to secure a modification of the rule of liability of the common carrier. Justice Bronson, in the case of Hollister v. Nozwlen, ${ }^{8}$ thought the reasons for the rule lost little of their force when applied to the conditions of his day. "With what resistless force does not this reasoning apply to the ten thousand incorporations of our own country," said Nisbet, J., in the powerful opinion in Fish v. Chapman. And Mr. Justice Bradley, in the still more important Lockwood case, ${ }^{10}$ felt that more than ever the conditions of his day required the perpetuation of this protection to the shipper, although, as we shall see, he approved a rule permitting the carrier to make special agreements with the shipper within certain limits. He seems not to have seen that the result of this would be practically to nullify the old common law rule of the liability of the common carrier in a great portion of the carrying business of the country. Dpwn to the present day not one of our courts has admitted that there should be any relaxation of the strict rule, except it be by the shipper's consent. The practical result of this exception, and its enormous importance, we shall presently examine, but at this point we merely notice that the courts still continue to declare that the common carrier is by common law an insurer of the goods he carries, except for losses due to the act of God, the public enemy,

\footnotetext{
${ }^{7}(1876) 94$ U. S. II3.

${ }^{8}(\mathrm{I} 838)$ I9 Wend. 234.

${ }^{\circ}$ (I847) 2 Ga. 349, 36r.

${ }^{10}$ (1873) I7 Wall. 357.
} 
public authority, the act of the shipper himself, or the inherent vice of the thing shipped. And yet everywhere the great carrying corporations, as a matter of fact, have ceased to be so liable. How the special contracts, and certain statutes as they have been interpreted and enforced by the courts, have worked this apparent paradox, we are now ready to discuss.

II.

In the leading case of Hollister v. Nowlen, ${ }^{11}$ Justice Bronson has traced the departure in England from the wholesome rule of the common law, beginning with Nicholson v. Willan, ${ }^{12}$ in I804, and the disastrous results, calling for legislation by Parliament to bring the law back to its condition before the departure by this piece of judicial legislation. This unfortunate change was accomplished by allowing the carrier to limit the common law liability by public notice. The New York court refused to follow the English rule, and Hollister v. Nowlen has become authority in every State in this country for the doctrine that the carrier cannot by notice, even though it be brought home to the shipper, limit his common law liability. "Putting the matter in the most favorable light for the carrier, the mere delivery of goods after seeing a notice, cannot warrant a stronger presumption that the owner intended to consent to a restricted liability on the part of the carrier, than it does that he intended to insist on the liabilities imposed by law; and a special contract cannot be implied where there is such an equipoise of probabilities." ${ }^{\prime 3}$ This logic was so clear and convincing that it has been accepted by all our courts. What the court meant was, of course, not merely that the presumption was no stronger in favor of the restriction, but that on the other hand it was stronger that the shipper would insist on the greater right given to him by law, and that he would never assent willingly to the restricted liability, or at least that this assent would not be implied from the fact that he shipped after knowing the proposed restrictions.

But suppose the shipper had expressly consented to a restricted liability? Judge Bronson said that he would not deny that the carrier may by express contract restrict his liability, though the reasons for such a rule are not the most conclusive. If so, it must

"(1838) I9 Wend. 234.

${ }^{12} 5$ East, 507.

${ }^{13}$ Hollister $v$. Nowlen, supra, p. 248 . 
be on the ground that the person entrusted with the goods, although he usually exercises a public employment, in the particular case throws off this public employment and becomes like other bailees for hire, answerable only for negligence or misconduct. If he acts as a carrier, the court finds it hard to see how he can make a valid contract to be discharged from a duty or liability imposed upon him by law. The doubt expressed in this case the New York court was presently called upon to resolve, and it then denied that even by assent on the part of the shipper could the carrier secure the restricted liability. Cowen, J., speaking for the court in Cole v. Goodwin,"14 said: "My conclusion is that he (the carrier) shall not be allowed in any form to higgle with his customer and extort one exception and another, not even by express promise or special acceptance any more than by notice. . . . He is a public servant with certain duties defined by law; and he is bound to perform those duties." This was a case of clear assent by the shipper to a general notice, but this the court thought void as contrary to the plainest principles of public policy.

In Gould v. Hill, ${ }^{15}$ four years later, a case arose involving a special contract. The court emphatically reaffirmed this view, and extended it to cover not merely a general notice assented to but also a special contract between the carrier and the shipper.

We may notice one or two references to the question by other courts. In 1839 the learned Chief Justice Gibson, in Atwood v. Reliance Transportation Co., ${ }^{16}$ referred to the unfortunate direction of the English decisions, and expressed a doubt whether a contract to lessen the common law measure of the liability of the common carrier is not void by the policy of the law. And eight years later, Nisbet, J., in the case already referred to, Fish v. Chapman \& Ross, ${ }^{17}$ after an elaborate review of the cases, found that anterior to 1776 no adjudication in this country had relaxed the stringent severity of the law which made the common carrier an insurer for the delivery of goods entrusted to him, and liable for loss occasioned by all causes except the act of God and the King's enemies, and without the power to limit his responsibility. He approved the note of Mr. Wallace, in his edition of Smith's Leading Cases: "That it is possible for a common carrier, by

\footnotetext{
${ }^{14}(1838)$ 19 Wend. 25I, 28I.

${ }^{15}$ (N. Y. I842) 2 Hill, 623.

${ }^{16}$ (Pa. I839) 9 Watts, 87.

${ }^{17}$ (I847) 2 Ga. 349, 360.
} 
either general notice or a special acceptance to limit his extraordinary liability, is a position which it is believed is not supported by the authority of any adjudged case in the United States,' I Smith's Leading Cases, I83," and he adheres "to the sound principles of the common law, sustained by the courts of our own Union," and holds "notices, receipts and contracts in restriction of the liability of the common carrier, as known and enforced in I776, void, because they contravene the policy of the law." The only modification he admits is the right of the carrier by notice brought home to the shipper to require the latter to state the nature and value of his goods. This use of a notice by a carrier has never been objected to by any court. Such a notice is not a contract and does not require the assent of the shipper. Its use is but one of the "reasonable regulations which every man should be allowed to establish for his business, to insure regularity and promptness, and to properly inform him of the responsibility he assumes."18

III.

Such was the state of the law in 1847 , after more than half a century of adjudications by our courts, but in the very next year, in a case that could have been decided without considering the question, Justice Nelson wrote a paragraph in his opinion in the leading case of New Jersey Steam Nav. Co. v. Merchants' $B a n k,{ }^{18}$ which reversed all this. The case was perhaps the most momentous ever decided in this country upon the carriers' liability. Standing as it has been shown the authorities did down to that day, can any one doubt that, if the Supreme Court of the United States had added the weight of its decree to the rule that the common carrier was an insurer and could not in any way change its liability, it would for all time have settled the law on this subject? The carrier would have remained an insurer, and would it not have been to his advantage, as well as to that of the shipper? The slight additional cost of insurance would have been spread by the carrier over his tariffs, and eventually paid by the public. The shipper would have been protected by the payment of a slight additional cost to his carrying charges, and both would have been saved the huge cost of litigation that from that day to this has flooded the courts with questions about the limitations of the carrier's liability. Moreover, the carrier would have avoided

${ }^{15}$ Per Cooley, J., in McMillan v. M. S. \& N. I. R. R. (I867) I6 Mich. 79, III.

${ }^{10}$ (I848) 6 How. 344 . 
much of the resulting irritation and ill will on the part of the public, the weight of which the carrier feels in every case submitted to a jury in which the liability of the carrier is involved, as well as in a great deal of harsh, and even unjust, legislation to which the carrier has in recent years been subjected. Indeed when one considers the vast extent of the litigation that has taken place over this question of the liability of the common carrier, he is impressed with a view that the carrier out of the sums that he has wasted on litigation might have paid for all his losses under the common law rule, for the public has persistently refused to be content with this rule made by the courts. In many of the States, by statute or constitutional provisions, it has endeavored to restore the old law and, in the face of the most strenuous opposition from the carrier, it has accomplished something in Congress in the various provisions of the Interstate Commerce Act. Although, as will later appear, the Carmack Amendment to the Hepburn Act of 1906 and later amendments have done much, the shipper seems to be far from satisfied with the rules now existing on interstate shipments. Perhaps the Interstate Commerce Commission, with its broadening powers, has done more for him than any other federal provision. "The right of the common carrier to limit or diminish his general liability by a special contract has given rise to as much, if not more, discussion and contrariety of opinion" said the court in Capehart v. Seaboard Air Line R. R., ${ }^{20}$ "than any other question of law." It might be supposed that after all these' years the general rule of liability would be well settled. That this is not so is evident from a study of the digests. ${ }^{21}$

${ }^{2}$ The following, out of many recent cases, in which the courts have found it necessary to insist upon the rule that never satisfies, and to reannounce the old common law doctrine that the carrier is an insurer, will illustrate the persistence of the shipping public in its antagonism to the restricted liability. United States,-Inman \& Co. $v$. Seaboard Air Line Ry. (C. C. I908) 159 Fed. 960.

Alabana,-Barron v. Mobile etc. R. R. (IgII) 2 Ala. App. 555. California,-Stockton Lumber Co. v. California etc. Co. (I909) 1o Cal. App. 197. Delazeare,-Klair \& Hollingsworth v. Philadelphia etc. R. R. (IgII) 25 Del. 274 Georgia,-Louisville etc. R. R. v. Warfield \& Lee (1907) I29 Ga. 473. Illinois,-Mahaffey v. Wisconsin Central Ry. (1909) 147 Inl. App. 43. Indiana,-Cleveland etc. Ry. v. Henry (1908) I70 Ind. 94 Iowa,-Swiney v. Am. Ex. Co. (1908) I44 Iowa, 342 . Kansas,-Watkins Co. v. Missouri etc. Ry. (1910) 82 Kan. 308. Kentucky,-Chesapeake \& Ohio Ry. v. Williams (Ig13) $156 \mathrm{Ky}$. II4. Missouri,-Cunningham v. Wabash R. R. (I9I2) I67 Mo. App. 273. Nebraska,-Sunderland Bros. v. Chicago etc. Ry. (IgrI) 89 Neb. 660.
} 
As this agitation in courts and legislatures seems to show that the end is not yet, it may not be amiss in setting forth what the law is and what the forces at work indicate it may become, to point out that not only are the carriers in position, without hardship, to become insurers to the full extent of the old common law rule, but they have a real opportunity to do a profitable insurance business by insuring even against the act of God, making therefor, not the present unscientific and often extravagant charge, but a reasonable charge based upon tables worked out from experience, on the same plan as is followed in fixing rates for life and fire insurance. Outside companies are now writing such insurance on shipments, often at a small fraction of the extra charge demanded by the carrier for less extensive insurance. ${ }^{22}$ But the carrier has an organization and a full quota of agents and offices. It seems reasonable, therefore, to suppose he could do this insurance at a profit at a much less cost than any outside insurance company. Incidentally he could accumulate a store of public good will which would be very convenient in many critical days to come, when the carrier is asking favors or rights from commissions and legislatures. If it be said that the small carrier might be ruined by his losses in a single case, and that his business is not extensive enough to furnish any basis for charges, it may be answered that he is, in general, now carrying without restrictions, while it is the great railway, express, and steamship lines that practically compel exemptions from the public by so-called contracts. Furthermore the small carrier might be excepted from this larger liability, or he can easily reinsure his risks with indemnity companies. Such an extension of service, of course, will not come at the hands of the courts. It must be either voluntary or by legislation. The writer believes that if the carrier would make it voluntary he might earn some of the good will of the public, so often sorely needed, and do something to restore that right relation between carrier and public so necessary to assure to the public satisfactory service and to the carrier a profitable business. To make scientific insur-

New York,-Gardiner ø. New York Central \& H. R. R. (I9Io) I39 App. Div. I7.

Oregon,-Lacey $v$. O. R. \& N. Co. (I9I3) 63 Ore. 596. 263.

Texas,-Abbott Gin Co. v. Missouri etc. Ry. (rgo9) 57 Tex. Civ. App.

West Virginia-Hutchinson v. U. S. Ex. Co. (I907) 63 W. Va. 128.

${ }^{22}$ See In re Express Rates, etc. (I912) 24 I. C. C. R. 395, 397. Since the above was written Congress has passed the Cummins Act (S. 4522, approved March 4, I915) making important modifications in the Carmack Amendment. 
ance rate tables based upon experience should be no more difficult than similar tasks by other insurance companies. The Interstate Commerce Commission may find time to do this, and be given by the legislature power to impose it on the carrier. This compulsion would rob the carrier of all the good will that might be secured by a voluntary offer. The true good of the carrier and of the public he serves, and on which he depends for his earnings, are more nearly identical than is sometimes assumed.

We must now return to 1848 and the great case of New Jersey Steam Nav. Co. v. Merchants' Bank. ${ }^{23}$ The loss for which suit was brought was caused by the gross negligence of the carrier, and the court might have disposed of the case, as did Bronson, J., of Hollister v. Nowlen, supra, by saying that whatever might be the effect of a contract in some cases, this contract could not avail in this case. Indeed that is just what Justice Nelson finally did, but not until he had first gone aside to remark that though the New York court, of which, by the way, he was himself at one time a member, had held against such restrictions, he was unable to perceive any well founded objection to them. Every reason he gives for this conclusion has been utterly repudiated by the United States Supreme Court and every other court, and yet his conclusion stands, thereby reversing what has been shown to be the law universally in England to 1776 and in this country to 1848 . In the particular instance, said the judge, only the parties to the transaction are concerned, involving simply rights of property. "The owner, by entering into the contract, virtually agrees that, in respect to the particular transaction, the carrier is not to be regarded as in the exercise of his public employment; but as a private person, who incurs no responsibility beyond that of an ordinary bailee for hire, and answerable only for misconduct or negligence." ${ }^{24}$ So far from this being the case later decisions have settled that the public, as well as the parties to the transaction, is concerned in every contract and in the whole power to make any contract; that the owner cannot agree that as to him the carrier is not to be regarded as in the exercise of his public employment; and that the carrier cannot become an ordinary bailee for hire, cannot put off his public employment that is imposed upon him by law. The result of this Pyrrhic victory of the carrier has been costly, if not disastrous.

" 1848$) 6$ How. 344.

${ }^{2 \star}$ New Jersey Steam Nav. Co. v. Merchants' Bank, supra, p. 382. 
It is unnecessary to notice in detail how the state courts followed the pronouncement by the high authority of this court. In New York the courts reversed the former rule, and drawing a natural inference from Justice Nelson's remarks about exemptions from liability for negligence, held that the carrier might contract against liability for losses, even if they were due to the negligence of the servants or agents of the carrier. That could not be done, however, in general terms excluding liability from whatever cause arising, but the contract must specifically mention negligence. The course of the New York decisions is sufficiently set forth in the next case, to which we must now give attention. ${ }^{25}$

\section{IV.}

An interval of twenty-five years brings us to the greatest case on this question. In Railroad v. Lockwood, ${ }^{26} \mathrm{Mr}$. Justice Bradley delivered a masterly opinion that settled for nearly all jurisdictions the common law doctrine as to the matters touched upon by him. The case involved the liability of the defendant for injuries caused by negligence to one who was riding on a drover's pass which stipulated that the company should not be answerable for their own or their servant's negligence in reference to the carriage. "As the duties and responsibilities of public carriers were prescribed by public policy", said the court, "it has been seriously doubted whether the courts did wisely in allowing the policy to be departed from without legislative interference, by which needed modifications could have been introduced into the law." After reviewing the New York cases since I848, noting that the "fruits of the rule are already being gathered in increasing accidents through the decreasing care and vigilance on the part of these corporations," he points out that in England it was necessary to bring back the salutary policy of the common law departed from by the courts, by the Railway and Canal Traffic Act of 1854 . He next demolishes Justice Nelson's notion that in shipping contracts only the parties to the transaction are concerned, and that the

${ }^{25}$ See Mynard v. Syracuse etc. R. R. (1877) 7r N. Y. 180; Bissel $\%$ N. Y. C. R. R. (I 862 ) 25 N. Y. 442. The rule in New York is now fixed by Public Commissions Act, Session Laws (I907) c. 429, $\$ 38$, making stipulations against liability for losses caused by the carrier invalid. The New York courts have not very fully passed upon this part of the act, but see Boyle $v$. Bush Terminal R. R. (Igr4) 2ro N. Y. 389 , and cases cited; Jones v. Wells Fargo Ex. Co. (I914) 83 Misc. 508; Schwartz v. Fargo (I9II) I45 App. Div. 574.

${ }^{20}$ (I873) I7 Wall. 357. 
carrier by special contract may drop his character and become an ordinary bailee for hire, and therefore make any contract he pleases. His duties as a common carrier are imposed upon him, not by contract, but by law, and his nature as a common carrier cannot be changed by agreement. Nor is it of any avail to say that he is liable, if his liability for the acts of his agents and servants may be waived, especially where the carrier is an artificial person. As to the favorite argument that men must be permitted to make their own contracts, "and that it is no concern of the public on what terms an individual chooses to have his goods carried", the court finds that the whole business community is affected by holding such contract valid. "The carrier and the customer do not stand on a footing of equality. The latter is only one of a million. He cannot afford to higgle or stand out and seek redress in the courts. His business will not admit of such a course." Usually he must accept any bill of lading the carrier presents, or abandon his business. In the present case he must accept the restricted liability or pay three times the tariff rates. The evidence showed no drover ever made any other arrangement. The customer has no real freedom of choice, no practical alternative. The employment of the carrier is a public one charging him with the duty to serve the public. His business is mostly concentrated in a few powerful corporations whose position in the body politic enables them to impose such conditions as they see fit and to compel the public to accept them. "The status and relative position of the parties render any such conditions void." Contracts of common carriers "must rest upon their fairness and reasonableness." The court then cites examples of limitations introduced by the carrier and sustained by the courts because they were "reasonable and just." But all these illustrations are cases of rules and regulations that the carrier would have a right to impose by general notice without consent of the shipper, and in spite of his dissent. Strangely enough the learned judge did not see that they involved no contract, and indeed that his reasoning had made it clear that in a case where the parties stood on such unequal footing there could be no real contract, with freedom on the part of the shipper to assent or dissent to proposed terms. To say that one has made a contract if the terms are reasonable, but that his agreement is void if they are unreasonable, when it appears in both cases he was under a practical necessity to assent, is to ignore one of the essentials of contracts. The reasonableness or unreasonableness of the 
proposed terms has no bearing on the question of whether there is a contract, though of course it might have on the question of public policy. What the Lockwood case really did was to enable the carrier to throw off his common law liability, in so far as it was considered by the court to be reasonable to allow him to do so. He could not, however, do this by a general notice brought home to the shipper, but must secure at least the form of an assent. This he may do by giving to the shipper a bill of lading, assent to the terms of which is in most States conclusively presumed from its acceptance, though probably most shippers, as a matter of fact, have not read them and do not know them, often are ignorant of their existence on the bill of lading. ${ }^{27}$

Justice Bradley perhaps felt that after the twenty five years since New Jersey Steam Nav. Co. v. Merchants' Bank, ${ }^{28}$ the question of legality of contract limitations was stare decisis, and all the court could do now was properly to safeguard the use by the carrier of the so called contract. He does not seem to have seen what a flood of litigation was to ensue to determine what was "reasonable and just," nor that carriers would continue to print in their bills of lading stipulations that had again and again been held by every court passing upon them to be null and void because unreasonable and unjust. ${ }^{29}$ The unfortunate effect of this conflict is well brought out in the very able opinion of Commissioner Lane in In re Released Rates. ${ }^{30}$ The Lockwood case at least settled this, though the New York courts refused to reverse themselves a second time in order to come into accord with the United States Supreme Court, that in almost every State the carrier was forbidden to contract against liability for losses due to its negligence. Practically any other restriction was held to be reasonable and just.

And now the carriers entered upon another campaign to break through the lines drawn around them. With great variety of ingenious strategy they sought the weak places in the fortifications the Lockwood case had set up for the protection of the public.

\footnotetext{
${ }^{27}$ Compare McMillan v. M. S. \& N. I. R. R. (1867) I6 Mich. 79 with Kirby v. C. \& A. R. R. (I909) 242 t11. 4I8, and Wabash R. R. v. Thomas (I906) 222 I11. 337, and cases cited, to the effect that mere acceptance or signing of a bill of lading is not conclusive of assent to its terms.

"See for example the form of receipt in general use by the express companies to the close of 1913 , and by railroads until the adoption of the uniform bill of lading in Igos which will receive further attention presently.

${ }^{30}$ (I908) 13 I. C. R. 550.
} 
Not only did the carrier, as above noted, continue to print void stipulations, with the view no doubt of thereby preventing many shippers from pushing just claims, ${ }^{31}$ but they found a new line of attack by attempted limitations upon the amount of their liability. The conflict over such stipulations has raged fiercely in the courts and in the legislatures to the present day. So far as the courts are concerned we shall see that a conclusion seems to have been reached largely adverse to the contentions set up by the shippers. In the legislatures there has been great pressure, sometimes by dishonorable and corrupt efforts, to control. The result at present largely favors the desires of the carrier because of the recent decisions by the federal courts of cases arising under the Carmack Amendment to the Hepburn Act, though as regards intrastate shipments in many States the written law forbids any modification, by contract or otherwise, of the common law liability of the carrier. There are signs that the struggle is not yet over in Congress, and the unfortunate part of this, as of all wars, is that it seems so needless, and that it results in so much bitterness that both sides suffer severely. It can hardly be doubted that the railroads have submitted to much irritating and unjust legislation which has been induced by the bad feeling growing out of this conflict. As the true interest of the public cannot be served without fair and generous treatment of such an important servant as the common carrier, the results are most unfortunate for both parties concerned.

$$
\text { v. }
$$

On the limitation of the amount of the liability the most important case is Hart v. Pennsylvania $R$. $R .{ }^{32}$ decided in 1884 . A number of cases had been passed upon in state courts in which the carrier had inserted in the bill of lading a term that it would not be liable in case of injury or loss beyond a certain amount, as, for example, for more than $\$$ Ioo per head in the case of horses. $^{33}$ The Minnesota court thought it absurd to say that the carrier cannot be absolved from liability for damages caused by his own negligence even by the agreement of the parties,

\footnotetext{
${ }^{31}$ See for further illustrations, such cases as two from Texas Civ. App., Atchison, etc. Ry. $v$. Smythe (1909) 55 Tex. Civ. App. 557, in which the bill of lading provided against liability for injuries from collisions or derailments, and International etc. R. R. $v$. Vandeventer (Ig08) 48 Tex. Civ. App. 366 , in which the restriction covered all liability except for gross negligence.

${ }^{20}$ I1 2 U. S. 33I.

${ }^{33}$ Moulton v. St. Paul etc. Ry. (I883) 3I Minn. 85.
} 
"but that one half or three fourths of this burden, which the law compels the carrier to bear, may be laid aside by means of a contract limiting recovery of damages to one half or one fourth of the known value of the property." A number of cases pro and con are cited in the Hart case. There suit' was brought for $\$ 19,800$ for the death of one race horse and injury to four others through the negligence of defendant in transporting them. The bill of lading recited that the plaintiff is to pay the rates of freight expressed "on the condition that the carrier assumes a liability on the stock to the extent of the following agreed valuation: if horses or mules, not exceeding $\$ 200$ each." After approving the Lockwood case, the court states the established rule that if the shipper misrepresents the nature or value of the articles he destroys his claim to indemnity. It then adds that if the shipper secures a low rate of freight upon a representation of value fairly made there is no justice in allowing him to recover of the carrier a large value for the loss of the article. This does not excuse from liability for negligence. "It does not induce want of care. It exacts from the carrier the measure of care due to the value agreed on. The carrier is bound to respond in that value for negligence. The compensation for carriage is based or that value. The shipper is estopped from saying that the value is greater."

There can be no question of the soundness of this rule if so limited, that is if all the elements of estoppel are present. But one cannot invoke estoppel unless he was misled by the other party to his prejudice. If the carrier does not know the value, and is misled by the shipper so that he believes the goods have a less value than they have, and fixes a low rate of carriage accordingly, it would be manifestly unjust and unreasonable to allow a greater recovery than that named, the shipper is estopped to set up a greater value. But if, as often happens, the carrier knows that the declared value is not the true one, but consents to a lower rate in return for a lower valuation by the shipper, then there can in principle be no estoppel. To the extent that the so-called "agreed value" is less than the known true value of the shipment, it is an agreement between the carrier and the shipper that the carrier shall not be liable for his negligence, and this the Lockwood case utterly forbids. The carrier, if he knows this is an undervaluation, is a party to the illegality, and is in no position to invoke estoppel against the other party. The reasoning has the greater force when it appears, as it usually does, that the shipper had no 
actual knowledge of the agreement, and his knowledge is imputed to him by law in spite of his actual ignorance. To give validity to such connivance between carrier and shipper is to nullify the rule of the Lockwood case, and enable a carrier to contract against negligence to the extent of the known value of a race horse in excess of $\$ 20,34$ and of a carload of automobiles in excess of $\$ 50^{35}$ As was pointed out in the dissenting opinion in the last case, the $\$ 50$ limitation in a case of property of a doubtful or uncertain value may very well be upheld, but a "valuation of $\$ 5^{\circ}$ upon $\$ 15,000$ worth of property-of known value to both carrier and shipper-is not a valuation at all, but is an arbitrary and unreasonable limitation in the guise of a valuation." If this may be done, then the most valuable article may be valued at a penny! If, in the langnage of the prevailing opinion, "it would be in the highest degree violative of public policy to permit a shipper who has pecuniarily benefitted by the valuation he has deliberately agreed upon to repudiate his agreement and recover against a carrier on a higher valuation," then by the same reasoning it would be violative of public policy to allow a shipper who has secured a lower rate by releasing the carrier from the last $\$ 50$ of liability to recover anything at all, and yet such an agreement is utterly void. This has been very ably stated in the dissenting opinion of Pitney, J., in Boston \& Maine Ry. v. Hooker :" "An estoppel cannot arise unless the party invoking it has been the victim of misrepresentation and has himself acted in good faith." If the carrier has arbitrarily fixed the value, regardless of the actual value of the property, it has not acted in good faith, nor has it been the victim of misrepresentation. "No estoppel arises where the conduct of the party sought to be estopped is due to ignorance founded upon an innocent mistake; and the same is more evidently true when the innocent party is silent because not asked to speak and unaware that there is occasion-much less, duty-to speak. There is, I think, no support in reason or authority for holding that a person acting in good faith, but in ignorance of his rights or of the rights of the other party, should be estopped upon the ground of knowledge imputed to him by a mere fiction of the law. It is only when good faith requires one to speak that silence estops him. .. . . Estoppel in pais presupposes an actual fault or a

"Donlon v. Southern Pac. R. R. (1907) 15x Cal. 763 .

${ }^{25}$ George N. Pierce Co. $v$. Wells Fargo \& Co. (C. C. A. IgII) I89 Fed. $56 \mathrm{r}$, affirmed in an opinion handed down by the U. S. Supreme Court, Feb. 23. 1915 .

(1914) 233 U. S. 97, I42-I43, I45. 
culpable silence." The learned justice held that the Railway Company did not in any wise rely on the plaintiff's silence. There is more reason to hold the company itself estopped because it and not the plaintiff had knowledge of the regulation and also of the value of the goods.

Thus, whether we consider the matter from the point of public policy, or as an application of the principle of estoppel, it seems clear on reason that Commissioner Lane in his opinion before referred to, ${ }^{37}$ took the only sound position. "When the shipper has placed upon his goods a specific value, the carrier accepting the same in good faith as their real value, the rate of freight being fixed in accordance therewith, the shipper cannot recover an amount in excess of the value he has disclosed, even when loss is caused by the carrier's negligence. . . . If the specified amount, while purporting to be an agreed valuation, is in fact purely fictitious and represents an attempt to limit the carrier's liability to an arbitrary amount, liability for the full value cannot be escaped in event of loss due to negligence. . . . If the shipper and carrier collusively agree that, for the purpose of the transportation, the property shall be deemed to have a specified value, which both know to be grossly disproportionate to the true value, the agreement cannot be called bona fide. It may be styled an 'agreed valuation', but it is obviously an attempt to accomplish what the law forbids."

This finding of the Commissioner has not, of course, the authority of the decision of a court. When we turn to the state courts we find a hopeless confusion. Some wholly refuse to recognize limitations as to value. ${ }^{38}$ Others uphold limitations as to value, even in cases where the carrier knew the "agreed value" was arbitrary and had no relation to the true value. The most extreme case is Geo. N. Pierce Co. v. Wells Fargo \& Co., ${ }^{39}$ where recovery for a $\$ 5,000$ carload of automobiles shipped by express was limited to the $\$ 50$ valuation named in the receipt. The goods were fully described in writing, but the receipt was stamped "Value

\footnotetext{
${ }^{37}$ In re Released Rates (I908) I3 I. C. R. 550, 553, 556.

${ }^{35}$ See Southern Ex. Co. $v$. Owens (Ig06) I46 Ala. 4I2; Kansas City etc. Ry. v. Embry (1905) 76 Ark. 589; Central of Georgia Ry. v. Hall (1905) I24 Ga. 322 ; Southern Ex. Co. v. Marks etc. Co. (Igo5) 87 Miss. 656; Paul v. Pennsylvania R. R. (I904) 7o N. J. L. 442; Stringfield v. Southern Ry. (I9IO) I52 N. C. I25; Eckert v. Pennsylvania R. R. (I905) 2 II Pa. 267; Baltimore \& Ohio R. R. v. Oriental Oil Co. (I908) 5 I Tex. Civ. App. 336; Clarke-Lawrence Co. $v$. Chesapeake \& Ohio Ry. (Igo8) 63 W. Va.

${ }^{\$}$ (C. C. A. I9II) I 89 Fed. 56I, affirmed in an opinion handed down by the U. S. Supreme Court on Feb. 23, I9I5.
} 423 . 
asked and not declared". It appeared in the case that the shipper knew the limitation and deliberately chose to ask the lower rate. If such a contract is void as against public policy, of course it could not bind even so, but the court upheld it. ${ }^{40}$

Still other cases make distinctions. When concealment or fraud is practiced on the carrier, such limitations as to value may well be upheld. The carrier has a right to know the nature and value of the articles offered for shipment, and if he in good faith seeks to learn it from the shipper estoppel may well be invoked if the shipper later claims a greater value. Thus, when Persian shawls and rugs are described as a second-hand desk, the recovery for their loss should certainly be limited to the value of such a desk. ${ }^{41}$ So, too, if the shipper himself fills in the value at $\$ 50$ and the carrier has no other knowledge of the nature or value of the goods, the limitation should be good. ${ }^{42}$ The same consideration should limit to $\$ 50$ recovery for loss of a pasteboard box containing jewelry worth $\$ \mathrm{r}, 435$, it appearing that the carrier had no knowledge of the contents. ${ }^{43}$ But quite other considerations ought to govern a claim by a carrier of a $\$ 50$ limitation on a shipment of $\$ 2,000$ worth of strawberries on which the carrying charges were $\$ 330$, or a limitation to twenty cents per cubic foot for monumental marble, ${ }^{44}$ or $\$ 50$ on a large consignment known to contain silk shirtwaists. ${ }^{45}$ The distinction is clearly seen by a comparison of Ostroot v. Northern Pac. Ry., ${ }^{46}$ and Larsen v. Oregon Shortline $R . R{ }^{47}$ In both cases household goods were shipped under a valuation of $\$ 5$ per hundredweight. In the former the court held that "it should require no argument to show that a valuation of $\$ 5$

\footnotetext{
${ }^{10}$ See also Bernard $v$. Adams Ex. Co. (1910) 205 Mass. 254, in which the court seems to make no question of whether the value is known to be greater than the agreed value; D'Arcy $v$. Adams Ex. Co. (I9I0) I62 Mich. 363 , in which the $\$ 50$ limitation of an express receipt was upheld as to a shipment of opals worth $\$ 372$, the carrier having notice and knowledge of the contents of the package; Douglass Co. $v$. Minnesota Transfer Co. (I895) 62 Minn. 288, apparently contrary to the other Minnesota Cases; Atkinson v. N. Y. Transfer Co. (1908) 76 N. J. L. 608, contrary to the opinion of the court in Paul $v$. Pennsylvania $R$. $R$. (I904) 7o N. J. L. 442; Greenwald $v$. Barrett (I9I0) Ig9 N. Y. I70, affirming Greenwald $v$. Weir (I909) I30 App. Div. 696, which overruled (I908) 59 Misc. 431 .

"Hachadoorian v. Louisville etc. R. R. (N. Y. I908) I28 App. Div. I7I.

"High Co. v. Adams Ex. Co. (Ig09) 5 Ga. App. 863.

${ }^{43}$ Porteous $v$. Adams Ex. Co. (I9I0) II2 Minn. 3I.

"Central of Georgia Ry. v. Butter Marble Co. (19ro) 8 Ga. App. I.

${ }^{45}$ Powers Mercantile Co. $v$. Wells Fargo \& Co. (1904) 93 Minn. I43.

${ }^{40}$ (IgIO) III Minn. 504.

${ }^{47}$ (I9IO) 38 Utah, I3O.
} 
per hundredweight when applied to pianos, cooking utensils and household goods, is intended as a mere arbitrary limitation of liability." In the latter the Utah court limited recovery for goods worth $\$ 40$ per hundredweight to the stipulated $\$ 5$ per hundredweight, the goods being described as a "roll of carpet including one feather bed", and the carrier not being further informed as to their nature or value. The question is fully discussed in Hansen $v$. Great Northern $R y .{ }^{48}$ the court concluding that a value in a bill of lading which is set without inquiry or investigation as to the true value of the property, is arbitrary, is not reasonable and just, and is therefore invalid, but an actual bona fide valuation is binding, notwithstanding the shipper, without the connivance of the carrier, has, to secure a lower rate, undervalued his goods. The same court in Schlosser v. Great Northern $R y^{49}$ made the novel holding that if one person is bound to ship goods to another the carrier becomes the agent of the consignor, and as such is liable to a third person, the consignee, for the tort of negligently injuring or losing the goods. The consignee may sue either principal or agent, not on the contract, but in tort for the full amount of his damages. If this rule were to be generally approved, it would afford a means in a large class of cases of nullifying all attempts of carriers to limit by contract the amount of their liability. It is quite improbable, however, that it will receive any considerable recognition. ${ }^{50}$

\section{(TO BE CONCLUDED.)}

UNIVERSITY OF MrChIGAN.

Edwin C. Goddard.

4s (1909) I8 N. Dak. 324.

${ }^{4}$ (I9IO) 20 N. Dak. 406.

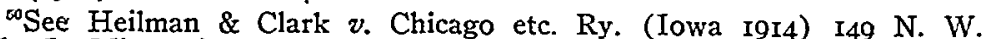
436. In Missouri Pacific Ry. v. Harper Bros. (C. C. A. I9I2) zor Fed. $67 x$, Baker, J., clearly states the law that carriers are insurers, but may by contract eliminate insurance and be liable only for negligence. They cannot go farther, and on consideration of lower rates escape liability for negligence. If liability for negligence cannot be avoided by deliberate contract, the logical consequence is that no practical part of such liability can be escaped. However, "reward ought to be proportionable to the risque," and so if valuation is in good faith and the rate based thereon, then the agreed value is the measure, not of the liability for the loss, but of the amount of the loss. In George N. Pierce Co. v. Wells Fargo \& Co. (C. C. A. IgII) I89 Fed. 56I, it may be there was no real relation between the value of the carload of automobiles and fifty dollars, and therefore the valuation was not fairly made. But there is no evidence in the case before the court to show a disparity between one hundred dollars and the fair average value of horses. 


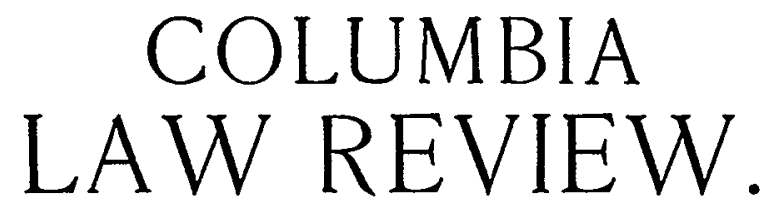

Vol. XV.

JUNE, 1915.

No. 6

\section{THE LIABILITY OF THE COMMON CARRIER AS DETERMINED BY RECENT DECI- SIONS OF THE UNITED STATES SUPREME COURT.}

VI.

In 1906 Congress enacted various amendments to the Interstate Commerce Act, most notable of which, as bearing on the question under discussion, was what is known as the Carmack Amendment to the Hepburn Act, ${ }^{81}$ which reads, "That any common carrier, railroad or transportation company, receiving property for transportation from a point in one State to a point in another State, shall issue a receipt or bill of lading therefor and shall be liable to the lawful holder thereof for any loss, damage, or injury to such property caused by it, or by any common carrier, railroad or tranportation company to which such property may be transferred, or over whose line or lines such property may pass, and no contract, receipt, rule, or regulation shall exempt such common carrier, railroad or transportation company from the liability hereby imposed; Provided, that nothing in this section shall deprive any holder of such receipt or bill of lading, of any remedy or right of action which he has under existing law."

This Act has now been passed upon by the United States Supreme Court in all its important parts. An early New York case, by a curious process of reasoning, arrived at the conclu-

${ }^{51}$ Act June 29, 1906, c. 3591, Sec. 7, 34 Stat. 595 [U. S. Comp. Stat. Supp. I9I I, p. I307.] 
sion that "the liability hereby imposed" was the liability of the initial carrier for a loss occurring on the line of a connecting carrier. The liability for a loss on its own line the court thought was the same as before the statute was passed. ${ }^{\text {s2 }}$ The appellate court affirmed the decision ${ }^{53}$ and apparently followed this interpretation of the statute, as did Travis v. Wells, Fargo $\mathcal{E}$ Co. ${ }^{54}$ As New York by statute ${ }^{55}$ now forbids the exemption of any common carrier from liability for loss, damage or injury caused by it, the distinction is perhaps of but small moment, since in practically all jurisdictions the carrier is now forbidden to stipulate against liability for the results of its own acts, and the Carmack Amendment extends the provision to contracts against liability for acts of the later connecting lines. The constitutionality of the Carmack Amendment in making the initial carrier liable for losses on any part of the route has been upheld in Atlantic Coast Line R.R. v. Riverside Mills, ${ }^{58}$ and of another provision of the Interstate Commerce Act, requiring the issue of a bill of lading covering the whole route and, therefore, of the making of joint rates, in Norfolk \& Western Ry. v. Dixie Tobacco Co.57

The most important decisions for our present purpose require detailed attention. The proviso of the Carmack Amendment was promptly considered in many state and some Federal cases, with the unanimous conclusion that its purpose was to save the shippers the rights they already had under many state statutes, ${ }^{58}$ or holdings of the courts, ${ }^{59}$ and under some constitutional provi-

${ }^{52}$ Greenwald $v$. Weir (N. Y. 1909) 130 App. Div. 696.

${ }^{*}$ Greenwald $v$. Barrett (I9IO) I99 N. Y. I70.

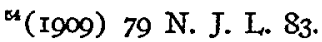

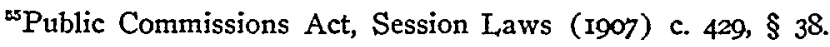

*(I9II) 2I9 U. S. I86.

${ }^{67}$ (I9I3) 228 U. S. 593.

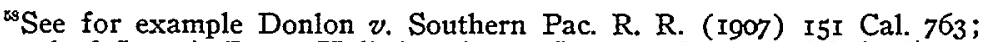
Central of Georgia Ry. v. Hall (I905) I24 Ga. 322; Cutter v. Wells, Fargo \& Co. (I908) 237 I1l. 247; Powers $v$. Chicago, R. I. \& P. Ry. (1905) I30 Iowa, 6I5; International etc. R. R. v. Vandeventer (I908) 48 Tex. Civ. App. 366; Norfolk \& Western Ry. v. Harman (1905) I04 Va. 50I; Southern Exp. Co. $v$. Keeler (I909) Iog Va. 459.

${ }^{*}$ Southern Exp. Co. v. Owens (Ig06) I46 Ala. 4I2; Kansas City Southern Ry. v. Carl (1909) 9r Ark. 97; Miller v. Chicago B. \& Q. Ry. (I909) 85 Neb. 458; Missouri etc. Ry. v. Harriman Bros. (Tex. Civ. App. I9I0) I28 S. W. 932; Atchison etc. Ry. v. Rodgers (I9II) I6 N. M. I20; Uber v. Chicago M. \& St. P. Ry. (IgI2) I5I Wis. 43I; Pace Mule Co. v. Seaboard Air Line Ry. (IgI2) I60 N. C. 215. 
sions $^{60}$ which provided in substance that no contract modification of the common law liability of the carrier should be valid."

All these cases were overthrown by the leading case of Adams Exp. Co. v. Croninger, ${ }^{62}$ decided June 6, I913. Following this decision, the court at the same time reversed and remanded the Latta and Miller cases cited, supra. In the Croninger case a diamond ring, for which plaintiff obtained a judgment of $\$ 137.52$ in the Kentucky Circuit court, had been shipped under an express receipt limiting recovery to $\$ 50$. On writ of error to the United States Supreme Court it was held that in the Carmack Amendment Congress had shown its intent to take over the whole subject of the liability of the common carrier on interstate shipments, and to supersede all state laws on that subject. The proviso that nothing therein contained should deprive the holder of a receipt or bill of lading of any remedy or right of action which he has under existing law, means under existing federal law. The court did not point out any existing federal law to which it could apply. So interpreted it is believed the proviso means absolutely nothing. The section did not deprive ${ }^{63}$ the shipper of a single right he had under federal law. On the other hand it did extend his rights, at least in the important matter of liability for losses on connecting lines. But this liability of the initial carrier did not deprive the shipper of his right against any other earrier to which the goods should be delivered. Indeed it expressly provided that any such common carrier should be liable for losses eaused by it. ${ }^{64}$ In the opinion, the court points out that Congress had not previously legislated upon this subject, which would seem to prove that there was no existing federal statute law to which the proviso could apply. Neither could it apply to any federal common law for the common law enforced in the federal

${ }^{60}$ Latta v. Chicago St. P., M. \& O. Ry. (C. C. A. Ig09) I72 Fed. 850, (C. C. A. IgII) I84 Fed. 987; Pennsylvania Co. v. Kennard etc. Co. (r899) 59 Neb. 435; Southern Exp. Co. ข. Fox (Ig09) I3I Ky. 257.

${ }^{\text {"But }}$ cf. Barnes $v$. Long Island R. R. (N. Y. I906) II 5 App. Div. 44, (Reversing 47 Misc. 3I8), affirmed (I908) I9I N. Y. 28, but construing the Kentucky constitution contrary to the construction adopted by the Kentucky court.

${ }^{62} 226$ U. S. $49 \mathrm{I}$.

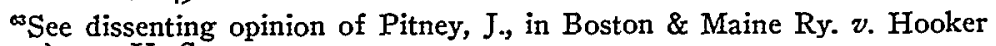
(I9I4) 233 U. S. 97 , I55.

Etastover Mule \& Horse Co. v. Atlantic Coast Line R. R. (S. C. I9I4) 83 S. E. 599; Baltimore etc. Ry. $v$. Sperber (I9I2) II 7 Md. 595; Uber $v$. Chicago, M. \& St. P. Ry. (I9I2) I5I Wis. 43I, following Tradewell $v$. Chicago \& N. W. Ry. (I912) I5o Wis. 259 ; see also dissent of Pitney, J., in Boston \& Maine Ry. v. Hooker (IgI4) 233 U. S. 97. 
courts is the common law of the several states in which actions may arise. ${ }^{65}$ The court seems first to have made up its mind that the great evil lay in the great variety and confusion of existing state rules. It concludes that it is very desirable that these should be reduced to a uniform rule, and therefore that that must have been the intent of Congress in passing the Carmack Amendment and taking over the whole subject of limitation of liability. Is it not much more probable that, if Congress had such an intent, it put in the proviso as a concession to objections from States where existing law was more favorable to the shipper than the provisions of the Carmack Amendment? It was assumed by every court passing upon the question, before the decision of the Croninger case by the Supreme Court, that the proviso was intended to save to the shipper whatever rights he had under existing state law. ${ }^{66}$ But whatever the views of the state courts before the Croninger case, all have accepted that as final, and, accordingly, limitations of liability as to value are upheld in interstate carriage by all courts, even those that still hold them void on intrastate shipments. ${ }^{67}$ Accordingly if the shipper wishes the rights and remedies he formerly had in certain States, he must get Congress to write into the proviso of the Carmack Amendment the word "state", where the courts hold Congress meant to imply "Federal", or perhaps secure a Federal enactment similar to the state enactments of Nebraska, Iowa and Kentucky, which forbid contract limitations of common law liability.

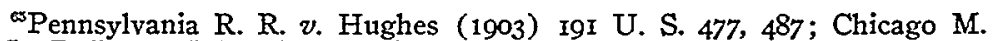
\& St. P. Ry. v. Solan (I898) I69 U. S. I33.

${ }^{e s}$ Southern Exp. Co. v. Hanaw (I9ro) I34 Ga. 445; Carpenter v. United States Exp. Co. (x912) 120 Minn. 59; Pace Mule Co. $v$. Seaboard Air Line Ry. (Igr2) 160 N. C. 215; Cramer v. Chicago R. I. \& P. Ry. (IgII) I53 Iowa, I03, and especially the following cases that were reversed by the United States Supreme Court: Miller v. Chicago B. \& Q. R. R. (Igog) 85 Neb. 458; Kansas City Southern Ry. v. Carl (I909) 9I Ark. 97; Missouri etc. Ry. v. Harriman (Tex. Civ. App. I9Io) I28 S. W. 932; Latta v. Chicago, St. P. M. \& O. Ry. (C. C. A. I909) I72 Fed. 850, (C. C. A. IgII) 184 Fed. 987 ; see Adams Exp. Co. v. Croninger (I913) 226 U. S. 49I, 5I3, 5I9; and Wells, Fargo \& Co. v. Neiman-Marcus Co. (I9r3) 227 U. S. $469,639,657$.

${ }^{\circ}$ United States Exp. Co. v. Cohn (I9I3) I08 Ark. II5; Kansas City \& Memphis Ry. v. Oakley (Ark. 1914) 170 S. W. 565; Appel Suit Co. v. Platt (Igr3) 55 Colo. 45 ; Nashville etc. Ry. v. Truitt Co. (1914) I4 Ga. App. 767; Wabash R. R. $v$. Priddy (I913) I79 Ind. 483; Metz v. Chicago, R. I. \& P. Ry. (I9I3) 9o Kan. 460; Louisville etc. R. R. v. Miller (I9I4) x 56 Ky. 677; Harrison Granite Co. v. Grand Trunk Ry. (I913) I75 Mich. I44; Joseph v. Chicago, B. \& Q. Ry. (I9r3) I75 Mo. App. I8; Missouri etc. Ry. v. Walston (I9I3) 37 Okla. 5I7; Pacific Exp. Co. v. Krower (Tex. 19I4) I63 S. W. 9. 
VII.

The question now arises, what is the position of the United States Supreme Court, which must in all interstate shipments be followed by all state courts, on a limitation of value which the carrier knows is not the true value of the property shipped. In the Croninger case the recovery was limited to $\$ 50$ for a diamond ring worth $\$ 137.52$. In the Latta case a recovery of $\$ 3,024.28$ for the loss of a mare and colt was reversed, and the recovery limited to $\$ 100$ each. In the Miller case a judgment for $\$ I, 3$ I5.5O for the loss of a stallion, shipped under a \$roo limitation, was reversed. But in none of these cases does it appear, any more than it did in the Hart case, that the carrier really knew the true value, though $\$$ roo for a stallion would seem to be a very low figure if the carrier knew the horse was a stallion; and the same may be said of the Harriman case in which a limit of $\$ 30$ for each bull and $\$ 20$ for each cow was upheld on a shipment of four bulls and thirteen cows, "show cattle" worth \$10,640.

But the most extended discussion of this point is in Kansas City Southern Ry. v. Carl. ${ }^{68}$ Household goods worth $\$ 75$ were packed in a box weighing 200 pounds, and shipped under a released valuation of $\$ 5$ per hundredweight. If the goods had not been so released the rate would have been $78 \mathrm{c}$ per hundredweight higher. These tariffs were on file with the Interstate Commerce Commission, but plaintiff was allowed to testify that he did not know of the two rates, and that if he had he would have paid the higher. Though household goods are not for ordinary purposes valued by hundredweight, yet weighing is doubtless the most convenient, if not the most accurate and natural, means for a carrier of goods to fix the values, that are at best very uncertain and difficult to determine. As the carrier did not know the true value here, it may very well be that the contract should govern in this case. But the decision is of interest in a larger way. It held that if a carrier has filed rate sheets (as by law it is now required to do) which show two rates based on value, it is legally bound to apply that rate which corresponds to the valuation. If the shipper accepts a certain rate based on such value named in the tariff sheets, he is bound by it and is estopped from setting up a greater value, as much as though he had been asked and had declared the value and made a special contract accordingly.

${ }^{\infty}$ (IgI3) 227 U. S. 639. 
"The ground upon which such a declared or agreed value is upheld is that of estoppel."

It has been before urged that there can be no estoppel if the carrier knows the declared value is not the real one, but the court does not seem to make this distinction. It goes on to say that the valuation declared upon as shown by the published rate must be conclusive in an action to recover for loss or damage a greater sum. "In saying this we lay on one side, as not here involved, every question which might arise when it is shown that the carrier intentionally connived with the shipper to give him an illegal rate, thereby causing a discrimination or preference forbidden by the positive terms of the Act of Congress and made punishable as a crime." But in Atchison etc., $R y . \mathrm{v}$ Robinson, ${ }^{89}$ the court cannot "lay on one side" that question, for it appears the shipper told the agent of the railway by telephone that he wished to ship "race horses" in time for some races next day." There was a verdict below for $\$ 1,500$, but the Supreme Court upheld a limit, as fixed by the rates paid, of $\$ 100$ for each horse. The railway, through its agent, knew the special value of the

${ }^{\infty}$ (rgr4) 233 U. S. I73; see also American Silver Mfg. Co. v. Wabash R. R. (1913) $174 \mathrm{Mo}$. App. 184, in which the shipper told the carrier that the goods were worth near \$5000., and recovery was limited to $\$ 41.70$ for half of them.

rothe position of the Supreme Court on this point was fully settled by its decision handed down February 23rd, 1915, since the above was written, in George N. Pierce Co. v. Wells, Fargo \& Co., 35 Sup. Ct. Rep. 351. The court upheld a judgment for \$50. for the loss of a carload of automobiles worth more than $\$ 15,000$. on the ground that the company had deliberately accepted a lower rate, and that to allow a higher recovery would defeat one of the principal objects of the Act which is to prevent discrimination. Congress was not long in dealing with that view of the effect of the Carmack Amendment. Only ten days after the Supreme Court had decided the Pierce case the Cummins Act (S. 4522) was approved, under the terms of which the carrier is liable, "for the full actual loss, damage, or injury to such property . . . notwithstanding any limitation of liability, or limitation of the amount of recovery, or representation or agreement as to value in any such receipt or bill of lading, or in any contract, rule or regulation, or in any tariff filed with the Interstate Commerce Commission; and any such limitation, without respect to the manner or form in which it is sought to be made is hereby declared to be unlawful and void." If the goods are hidden from view the carrier may require the shipper to specifically state in writing their value, and shall not be liable beyond the amount so specifically stated. The Cummins Act cannot of course be discussed in this paper, which was prepared some months before its passage. The full effect of it can only be determined by another series of decisions by the Supreme Court of the United States, but it may be noted that already the carriers have appeared before the Interstate Commerce Commission to present their view of the effect of the Cummins Act, and to ask for rulings by the Commission. See pamphlet, "Remarks of Mr. O. E Butterfield before the Interstate Commerce Commission April ro, rgr 5"; before the Interstate Commerce Commission $\$ 49$ (ex parte) Memorandum, Brief of Points of 
horses. How can it now invoke estoppel? It may be the carrier has still a right to exact the higher rate. ${ }^{71}$ The shipper, if he knowingly takes a lower rate, no doubt is liable to the penalties of the Elkins Act forbidding discrimination, ${ }^{22}$ and so is the carrier. But if when goods have been shipped on the lower the carrier has a right to refuse to deliver the goods until the shipper pays the higher rate, ${ }^{73}$ or to sue the shipper and recover the difference in rates, ${ }^{74}$ why has not the shipper an equal right to pay the higher rate and recover the full value? That seems to have been allowed, in reverse order, in American Exp. Co. v. Kimball $\&$ Nutter. ${ }^{75}$ The Robinson case seems to decide that he has not. The Carl case quotes with approval from the opinion of Commissioner Lane, in In re Released Rates, ${ }^{76}$ but overlooks, or fails to follow, his contention that valuations known not to represent the true value are arbitrary and mere attempts to limit liability, and therefore void. ${ }^{77}$

viII.

In the Carl case another important matter is discussed, namely, the difference in rates a carrier may make for larger responsibility. As before pointed out the carrier is in position to do an insurance business at a lesser rate than any outside company, and can easily gather a great volume of information from which to make tables of rates based on experience, similar to those in use by life and fire insurance companies. It should be noted that the carrier is not offering absolute insurance, as does an insurance company, but only insurance against losses due to his negligence. For other losses under contracts now in general use he is not liable in any sum. Under the Uniform Bill of Lading,

Oral Argument made by Francis J. James, and Interstate Commerce Commission $\# 49$ (ex parte) In $R e$ the Cummins Amendment, decided May 7, 1915 .

${ }^{7}$ Herminghausen $v$. Adams Exp. Co. (Iowa, I9I4) I49 N. W. 234; Texas \& Pacific Ry. v. Mugg (I906) 202 U. S. 242.

${ }^{72}$ But see the late case of Goldberg $v$. New York Central \& H. R. R. (N. Y. I9I4) I64 App. Div. 389 , in which it was held that a mistake by the shipper's agent in his statement of the kind of goods shipped would not defeat a right to full recovery. The agent did not "knowingly and wilfully" misrepresent. The mistake can therefore be corrected, the carrier can collect the excess freight at the higher rate, and the shipper can recover for his goods.

${ }^{73}$ Texas \& Pacific Ry. v. Mugg (I906) 202 U. S. 242.

"Louisville etc. R. R. $v$. Allen (IgI3) I52 Ky. I45.

${ }^{73}$ (N. H. I9I3) 86 Atl. 258, (I9II) 76 N. H. 8I ; cf. Heilman \& Clark v. Chicago \& N. W. R. R. (Iowa, I9I4) I 49 N. W. 436.

${ }^{76}$ (I908) I3 I. C. R. 550 .

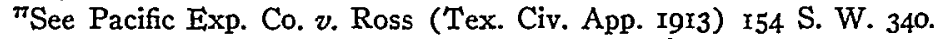


and by the form of express receipt approved by the Interstate Commerce Commission, as well as by the terms of the Carmack Amendment, the carrier is liable only for losses "caused by it", that is by its negligence. The carrier's charges are differentiated on the amount of the liability for this negligence. Thus, in the Carl case the rate used was a released valuation of $\$ 5$ per hundredweight. If there was no release the tariff was $78 \mathrm{c}$ per hundredweight higher. There is no way on the facts stated to judge whether this was a proper cost of insurance in this case, but certainly it seems to indicate that the charge would have been the same for any value above the released value of $\$ 5$ per hundredweight, whether the goods were worth $\$ 75$ or $\$ 7,500$. This certainly is far from a fair charge for insurance, or a scientific basing of rates. For goods of large value, it is clearly too low; for old or broken household goods it is as clearly too high. This is even clearer in the Harriman case, decided at the same time. Live stock shipped at "owners risk" was valued at \$30 for each bull and $\$ 20$ for each cow. " $120 \%$ of the rates named in this tariff will be charged on shipments made without limitations of carriers liability at common law, and under this status shippers will have the choice of executing and accepting contracts for shipments of live stock with or without limitation of liability, the rates to be made as provided herein." That is, by paying a rate $20 \%$ higher, the Harriman Brothers would have been entitled to recover $\$ 10,640$ instead of $\$ 380$ for the four bulls and thirteen cows. That is certainly very cheap insurance. In the very recent case of Nashwille, etc., Ry. v. Truitt, ${ }^{78}$ the rate for restricted liability was $\$ 86$ per car, and for unrestricted $\$ 172$. The unlimited rate was double, in American Silver Mfg. Co. v. Wabash R.R. ${ }^{79}$ Commissioner Lane has pointed out," that "the differential should exactly measure the additional risk which the carrier assumes when the liability is unlimited. ${ }^{81}$ An increased charge of $20 \%$ is manifestly out of all proportion to the larger risk involved, and its virtual effect is to restrict the public to rates calling for limited liability." This he calls a mischievous practice, the abolition of which would do much to improve the relation between the rail-

${ }^{78}$ (rgr4) $14 \mathrm{Ga}$. App. 767.

"rgr3) r74 Mo. App. r84.

${ }^{80} I n$ Re Released Rates (1908) I3 I. C. R. 550, 565.

${ }^{51}$ See Metz v. Chicago, R. I. \& P. Ry. (I913) go Kan. 460, in which the court treats insurance by the carrier as in principle like fire insurance on a house. This is hardly so, for there is no compulsion to insure a house. 
way and the shipping public. It is in point that this well-nigh universal unjust additional charge for higher valuations results in most cases of valuable shipments in the false billing forbidden by the Elkins Act, which is condemned in the Harriman case. In the Carl case the court holds that "the difference between two rates upon the same commodity, based upon valuation, is presumably no more than sufficient to protect the carrier against the greater amount of risk he assumes by reason of the difference in value." In view of the hopeless want of business system illustrated in the varieties of insurance rates offered in the cases just cited, this seems a violent presumption. "When the higher rate is no more than to reasonably insure the carrier against the larger responsibility a real choice of rate is offered, and the shipper has no reasonable excuse for undervaluation. If the margin between the rates is unreasonably beyond protection against the larger risk, the shipper may be induced to misrepresent the value to escape the unreasonably high rate upon the real value. This would result in permitting the shipper to obtain a rate to which he is not entitled, and in the carrier's escaping from a portion of its statutory liability." This, it is submitted, is just what does happen in most interstate freight shipments, and this the Elkins Act specifically forbids and purports to punish.

The court disposes of this whole question by saying it is one of the administrative duties of the Interstate Commerce Commission, and that "to the extent that such limitations are not forbidden by law, they become, when filed, a part of the rate." Putting this with such cases as Atchison, etc., Ry. v. United States, ${ }^{82}$ and Int. Com. Comm. v. Union Pacific R.R., ${ }^{83}$ the conclusion seems to be that reasonable rates and reasonable differentials for different valuations are rate making matters committed to the Interstate Commerce Commission as part of its administrative duties. With them the courts have nothing to do unless it be made to appear that the rates fixed or approved by the Commission are not reasonable. Presumptively all rates now on file with the Commission are reasonable, but in any case no complaint can be made to the courts until the Commission has first been petitioned and has made its finding. ${ }^{84}$ Until, there-

${ }^{82}$ (I914) 232 U. S. I99, 220.

"(I9I2) 222 U. S. 54I, 547.

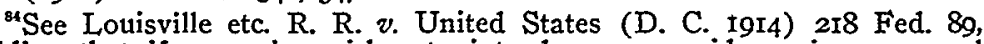
holding that if a carrier wishes to introduce new evidence in an appeal from the finding of the Commission it must first petition the Commission for a rehearing before it can appeal to the court. 
fore, the Commission finds time to undertake the enormous task of inquiry as to the rates that are a reasonable charge for insurance by the carrier, the present irregular and unscientific filed schedules of charges seem to stand, or at least until a party aggrieved, shipper or carrier, can secure "an order of the Interstate Commerce Commission readjusting the rates to meet the requirements of justice, alike to shipper and carrier." The courts will not consider the reasonableness of the schedules now on file until after "proceedings contesting their reasonableness before the Interstate Commerce Commission."

IX.

Furthermore, where the shipper accepts a classification or rate fixed in such filed tariff sheets he has made his contract. The carrier need make no other inquiry as to the value. ${ }^{86}$ It becomes part of his bill of lading, and he is compelled to take notice of the provisions of the rate sheets. ${ }^{87}$ The effect of this is to make "but one rate open to all alike and from which there could be

\footnotetext{
${ }^{85}$ Boston \& Maine Ry. v. Hooker (1914) 233 U. S. 97, I2I; Great Northern Ry. $v$. O'Connor (I9I4) 232 U. S. 508, 5'5, reversing O'Connor v. Great Northern Ry. (IgI2) II8 Minn. 223; George N. Pierce Co. v. Wells, Fargo \& Co. (IgI5) 35 Stip. Ct. Rep. 35I.

${ }^{80}$ Wells, Fargo \& Co. v. Neiman-Marcus Co. (r9r3) 227 U. S. 469.

${ }^{87}$ Great Northern Ry. v. O'Connor (IgI4) 232 U. S. 508; Robinson $v$. Louisville etc. R. R. (I9I4) 160 Ky. 235, citing the leading case of Atchison etc. Ry. v. Robinson (I9I4) 233 U. S. I73; Wabash R. R. v. Priddy (I9I3) I79 Ind. 483; Zoller Hop Co. $v$. Southern Pac. Co. (Ore I9r4) I43 Pac. 931; American Silver Mfg. Co. v. Wabash R. R. (I9I3) 174 Mo. App. I84; United Lead Co. $v$. Lehigh Valley R. R. (N. Y. I9I3) I56 App. Div. 525; cf. Kimball v. Express Co. (IgII) 76 N. H. 8I, in which the court allowed full recovery because the railway agent compelled the shipper to sign a limitation of value; International etc. Ry. $v$. Rathblath (Tex. Civ. App. I9I4) $167 \mathrm{~S}$. W. 75I, in which the court held that the carrier had the burden of showing consideration, and as no benefit to the shipper had been shown by the carrier the agreement was void. In Adams Exp. Co. $v$. Cook (Ky. App. 19r5) I72 S. W. I096, it was held that the carrier has also the burden of proving that its tariffs had been publicly filed, and in the absence of such proof the Interstate Commerce Act does not apply, and the shipper may recover full value; Yazoo etc. R. R. v. Peeples (Miss. Igr4) 64 So. 262 , holding that the Croninger case does not apply where evidence fails to show that a lower rate was granted for a lower valuation, based on schedule filed with the Interstate Commission; American Exp. Co. v. Merten (I914) 42 Okla. 492, in which a trunk with a bride's trousseau was not checked because it was too valuable, but was shipped via express with a statement to the agent that it was "very valuable". There was no written valuation by receipt, and the company failed to comply with the requirement, that it "issue a receipt or bill of lading therefor". Held, the company is liable for the full value, though the tariff charged was for a fifty-dollar valuation.
} 
no departure", 88 provided the rates are reasonably graduated and known, so that all alike will ship under the same rate. But the hardship on the shipper of this construction of the Hepburn Act, which was "intended to impose duties upon the carrier-the public servant-not upon the shipper or the passenger", is clearly brought out by Pitney, J., in his dissenting opinion in the Hooker case, before referred to. ${ }^{89}$ It compels him to know the effect of a bill of lading accepted by him, which contains no words showing the limitation except a reference to the value determined by the tariffs and classifications on file, and these are too complicated for the understanding of the average shipper, even if he knew of their existence. If they were always fair this would not perhaps be serious, but no stronger showing of the injustice of this scheme is needed than is seen in our analysis of the principal cases decided by the United States Supreme Court in reaching the rule.

The whole effect of the decisions upon the Hepburn Act is to make its sole purposes to extend the liability of the initial carrier, to secure on all interstate shipments uniformity, and to prevent discrimination. ${ }^{90}$ Though the tariffs now on file with the Interstate Commerce Commission are far from uniform, especially in the charges for the higher valuations, yet such tariffs, because they are on file, are presumed by the courts to be reasonable, and therefore all interstate shipments are now subject, both as to rates and as to value, to these tariffs, and will remain so until the Interstate Commerce Commission, on complaint or on its own motion, undertakes to examine and revise them. On the charges made for insurance it is to be hoped that the Commission may at an early day find time for a thorough inquiry, and a complete revision on proper principles, so that the shipper may be required to pay for insurance what it is reasonably worth. Then if he chooses to take a lower rate at "owner's risk", or at a limited value, there would seem to be no reason why he should not do so. This might go even to the extent of excusing the carrier from all liability, except that it will doubtless help to secure a better service and greater diligence from the carrier, if there hangs over him some penalty in the way of

\footnotetext{
${ }^{8}$ Boston \& Maine Ry. v. Hooker (1914) 233 U. S. 97, I12.'

${ }^{8}$ Supra, see especially p. 156 .

${ }^{80}$ This is fully justified by the opinion of Justice Day, read since the above was written: George N. Pierce Co. v. Wells, Fargo \& Co. (Feb. 23, I9r3) 35 Sup. Ct. Rep. 35I. But see The Cummins Act set forth in note 70 , supra.
} 
liability for losses due to negligence. On the other hand, the writer believes a more satisfactory relation between shipper and carrier would result from a voluntary assumption by all the great carriers of a liability as full insurers, against every hazard except the act of the shipper, at the lowest insurance cost consistent with a reasonable profit to the carrier from this insurance business.

$\mathrm{x}$.

Not only are all interstate shipments now made under the provisions of the tariff filed with the Commission, but they are subject to the contract on the Uniform Bill of Lading approved by the Interstate Commerce Commission, June 27, 1908. ${ }^{01}$ All carriers in such business are now therefore liable for losses caused by negligence, and the burden of proving freedom from negligence is on the carrier, but the amount for which the carrier is liable is "computed on the basis of the value of the property (being the bona fide invoice price, if any, to the consignee, including the freight charges, if prepaid) at the place and time of shipment under this bill of lading, unless a lower value has been represented in writing by the shipper, or has been agreed upon or is determined by the classification or tariffs upon which the rate is based . . . whether or not such loss or damage occurs from negligence." But as the rate paid by the shipper classifies the freight and limits the liability to the amount fixed by the tariffs for such rate, it would seem that the shipper can recover the actual value only when he pays a higher rate. In any case he cannot, of course, recover more than the actual value.

Express receipts, about one year ago, eliminated such void and illegal provisions of the forms long in use as "This Company is not to be held liable for any loss or damage, except as forwarders only," nor for the default or negligence of railways, steamboats, or other carriers by which the property is carried, and such carriers shall be deemed the agent of the shipper; nor for any loss or damage "from any cause whatever unless in every case the said loss or damage be proved to have occurred from the fraud or gross negligence of said Company or its servants." The company, under the new form of receipt, impliedly admits liability for losses caused by its own negligence, but in consideration of the rates charged, fixes the value at not exceeding $\$ 50$

${ }^{91}$ Bills of Lading (1908) I4 I. C. C. R. 346, 35I-355. 
for any shipment for less than Ioo pounds, nor at more than $50 \mathrm{c}$. per hundred in excess of Ioo pounds, unless a greater value is declared at the time of shipment and liability is limited to such amounts unless a greater value is stated and a greater charge paid, or agreed to be paid, therefor. ${ }^{92}$ Here again if the greater charge be fairly graduated the agreement is equitable, as well as legal.

Finally, it may be noted that the difference between the rule that estops the shipper to claim a greater value than that on which his carriage rate was based, and the rule that insists that estoppel can be invoked only when the shipper failed to reveal the true value and the carrier in good faith charged at a less value, is not perhaps in practice so great as it might seem. ${ }^{93}$ In many cases the carrier has no knowledge of the contents or the value of the shipment; in few eases does he actually know that the shipment is undervalued. Possibly with an end of the custom of rubber stamping receipts "Value asked and not given", when as a fact no value was asked or given, and with a little insistence that the carrier make reasonable effort, at least by simple inquiry, to learn the value, and then to bill accordingly, it would make no difference that the courts incline to hold as in the Robinson case. If under these circumstances the shipper does not state his value, then the results be on his own head, provided always he could be offered a fair choice at proper rates, between the lower and the higher value, so that he be not, as now, almost forced to what amounts to false billing. To this we are always brought back, namely, the urgent need of a fair adjustment of the varying rates for different values. It is to be hoped that the Commission will soon render a great service by working this out, for not only has the court left this to the Commission, but it is doubtless the body whose machinery and expert knowledge are best suited to attain ideal results. Certainly, neither the courts nor the legislatures are organized or equipped for accurate and efficient handling of the complicated administrative problems of insurance charges and rate making. The various public utility commissions have already done much to show that they are;

${ }^{22}$ See Express Rates, etc. (r9r3) 28 I. C. C. R. r3r, I37-r38.

${ }^{2}$ But by the decision of the U. S. Supreme Court in George N. Pierce Co. v. Wells, Fargo \& Co. (I9I5) 35 Sup. Ct. Rep. 35I, it was finally determined that it did not matter whether the carrier knew the true value. The valuation fixed by the rates governed in any case, for only so could all discrimination be avoided. But this has been nullified by the Cummins Act set forth in note 70 , supra. 
and notwithstanding some complaints, and some failures, the commissions have on the whole been able, not merely to gather a great mass of useful facts, and to formulate a useful body of fundamental principles, with valuable results to the public, but in some cases to render notable service to the carriers. ${ }^{94}$

EDWIN C. Goddard.

UNIVERSITY OF MICHIGAN.

of See, for example, the findings of the Interstate Commerce Commission, based on its investigation of the organization and business methods of the express companies. In $R e$ Express Rates etc. (I9I2) 24 I. C. C. $\mathrm{R}$. 380 ; Express Rates etc. (rgr3) 28 I. C. C. R. I3I. 